\title{
Anti-Convulsant Activity of Boerhaavia diffusa: Plausible Role of Calcium Channel Antagonism
}

\author{
Mandeep Kaur and Rajesh Kumar Goel \\ Department of Pharmaceutical Sciences and Drug Research, Punjabi University, Patiala, Punjab Pharmacology division 147002, India \\ Correspondence should be addressed to Rajesh Kumar Goel, goelrkpup@gmail.com
}

Received 8 August 2009; Accepted 19 October 2009

Copyright $\odot 2011$ M. Kaur and R. K. Goel. This is an open access article distributed under the Creative Commons Attribution License, which permits unrestricted use, distribution, and reproduction in any medium, provided the original work is properly cited.

\begin{abstract}
"Ethnopharmacological" use of roots of Boerhaavia diffusa (B. diffusa) in the treatment of epilepsy in Nigerian folk medicine and reports showing the presence of a calcium channel antagonistic compound "liriodendrin" in its roots, led us to undertake the present study. The study was designed to investigate the methanolic root extract of $B$. diffusa and its different fractions including liriodendrin-rich fraction for exploring the possible role of liriodendrin in its anti-convulsant activity. Air-dried roots of B. diffusa were extracted with methanol by cold maceration. The methanol soluble fraction of extract thus obtained was successively extracted to obtain liriodendrin-rich fraction and two side fractions, that is, chloroform fraction and phenolic compound fraction. Anti-convulsant activity of methanolic extract (1000, 1500 and $2000 \mathrm{mg} \mathrm{kg}^{-1}$, intraperitoneally (i.p.)) and its different fractions, that is, liriodendrin-rich fraction $\left(10,20\right.$ and $40 \mathrm{mg} \mathrm{kg}^{-1}$, i.p., chloroform fraction $\left(20 \mathrm{mg} \mathrm{kg}^{-1}\right.$, i.p.) and phenolic compound fraction $\left(1 \mathrm{mg} \mathrm{kg}^{-1}\right.$, i.p.) were studied in pentylenetetrazol (PTZ)-induced seizures $\left(75 \mathrm{mg} \mathrm{kg}^{-1}\right.$, i.p.). The crude methanolic extract of $B$. diffusa and only its liriodendrin-rich fraction showed a dose-dependent protection against PTZ-induced convulsions. The liriodendrin-rich fraction also showed significant protection against seizures induced by BAY k-8644. These findings reiterated the anti-convulsant activity of methanolic extract of $B$. diffusa roots. Furthermore, it can be concluded that the observed anticonvulsant activity was due to its calcium channel antagonistic action as this activity was retained only in the liodendrin-rich fraction, which has additionally been confirmed by significant anti-convulsant activity of liriodendrin-rich fraction in BAY k8644-induced seizures.
\end{abstract}

\section{Introduction}

Ayurveda is a native Indian healthcare system which is currently used by millions of people in India, Nepal and Sri Lanka for their day-to-day healthcare needs [1]. Boerhaavia diffusa Linn. (Nyctaginaceae), commonly known as punarnava in Sanskrit, is a creeping weed found abundantly all over India. It has a long history of use by indigenous and tribal people [2]. In traditional system of medicine, the roots of Boerhaavia diffusa ( $B$. diffusa) have been widely used for the treatment of dyspepsia, jaundice, spleenomegaly, abdominal pain, abdominal tumors and some other types of cancers [3]. In Charaka Samhita and Sushrita Samhita, it is mentioned that the Ayurvedic preparations made from punarnava-namely, punarnavastaka kvath, punarnava kshar and punarnava taila-were used for the treatment of various ailments such as stomachache, anemia, cough and cold, and used as laxative and expectorant. In Nigerian folk medicine it has been widely used for the treatment of epilepsy [4]. Many traditional uses of $B$. diffusa as, diuretic [5], anti-fibrinolytic [6], anti-bacterial [7], hepatoprotectant [8], anti-helmintic, febrifuge, anti-leprotic, anti-asthmatic, antiscabies, anti-urethritis [9], anti-convulsant [10], cardiotonic [11], immunosuppressant, anti-viral and anti-oxidant [12], anti-inflammatory [13], anti-diabetic [14] and anti-cancer [15], had been validated pharmacologically.

Boerhaavia diffusa contains a large number of phytoconstituents namely, flavonoids, alkaloids, steroids, triterpenoids, lipids, lignins, carbohydrates, proteins, glycoproteins, punarnavine, boeravinones A-F, hypoxanthine 9-1arabinofuranoside, ursolic acid, punarnavoside, punarnavoside and liriodendrin [12]. Liriodendrin was isolated from the methanolic extract of roots of $B$. diffusa and it showed a calcium channel antagonistic activity [16, 17]. Reports demonstrating the use of roots of $B$. diffusa in the treatment of epilepsy [10] and the presence of calcium channel 
antagonistic compound "liriodendrin" in its roots led us to hypothesize that, roots of $B$. diffusa may possess anticonvulsant activity due to calcium channel antagonistic effect of liriodendrin.

Hence the present study was designed to investigate different fractions of methanolic root extract of $B$. diffusa for exploring possible role of liriodendrin in its anti-convulsant activity.

\section{Methods}

2.1. Collection of Plant Material. Boerhaavia diffusa roots were collected from the botanical garden of Punjabi University, Patiala, India. The botanical identity of the plant material was verified and specimens were deposited at the Herbarium, Department of Botany, Punjabi University, Patiala, Punjab, for reference (Voucher No.: 50973).

2.2. Preparation of Liriodendrin-Rich Extract. Authenticated roots were shade-dried, grounded to a moderately coarse powder and were extracted as per the scheme given in Figure 1 [17]. Briefly, the dried powdered roots of the plant $(300 \mathrm{~g})$ were subjected to extraction with $500 \mathrm{~mL}$ of methanol thrice by cold extraction. The resultant methanolic extract was pooled and evaporated to dryness using rotavapor. The crude methanolic extract (32 g) (fraction 1) thus obtained was again dissolved in methanol (about $150 \mathrm{~mL}$ ) and the insoluble precipitate was separated by filtration which was found to be sucrose by Fehling's; test. The methanolic filtrate thus obtained was again evaporated to dryness using rotavapor and the residue thus obtained was suspended in water and fractionated by successive extraction with chloroform and butanol to give the chloroform (fraction 2), butanol and water fraction. The butanol fraction was extracted with $1.5 \%$ aqueous hydrochloric acid at room temperature and the insoluble material, which contained a mixture of phenolic compounds (fraction 3), was separated by filtration and the aqueous layer obtained from butanol fraction was pooled with aqueous layer obtained from methanolic solution. This pooled aqueous fraction was evaporated to dryness using rotavapor under reduced pressure. The residue thus obtained was dissolved in ethanol and the insoluble material was separated by filtration. The ethanolic solution was evaporated to dryness using rotavapor, giving the liriodendrin-rich fraction (fraction 4). The different fractions $(1,2,3$ and 4$)$ were stored at $4^{\circ} \mathrm{C}$ and the fractions of methanolic extracts were administered at a dose equivalent to the effective dose of crude methanolic extract based on percentage yield of each fraction. Dose of the extract and its fractions was prepared by dissolving a weighed quantity of extract and fractions in dimethylsulfoxide (DMSO) and then dispersing the resultant solution in $0.5 \%$ carboxymethylcellulose (CMC) suspension (DMSO 1: CMC 9) freshly before use and was injected intraperitoneally (i.p.). Control groups received equal volume of vehicle (DMSO 1: CMC 9) (i.p.).

2.3. Drugs and Chemicals. All standard chemicals used in the present study were of analytical grade. Pentylenetetrazol
(PTZ) was obtained from Sigma Chemical Company (USA), Diazepam from Jackson Laboratories Ltd (Amritsar, India), DMSO from Qualigens Fine Chemicals (Mumbai, India), CMC and Methanol from S.D Fine Chem Ltd (Mumbai, India) and BAY k-8644 from (Sigma-Aldrich, USA).

2.4. Animals. Male Swiss albino mice (Mus musculus), weighing 25-35 g obtained from Central Research Institute Kausali, Himachal Pradesh, were used in the present study. The animals were housed in standard cages and maintained at room temperature with natural day and night cycles. The animals were allowed free access to food (standard laboratory diet) and water during study. All experiments were carried out between 07:00 and 16:00 h. All procedures were conducted according to CPCSEA guidelines and approved by the Institutional Animal Ethical Committee.

2.5. Preliminary Phytochemical Screening. Crude methanolic extract of $B$. diffusa and its fractions 2,3 and 4 were reconstituted in methanol to obtain $1 \% \mathrm{w} / \mathrm{v}$ stock solutions, which were subjected to preliminary phytochemical screening for the presence of alkaloids (Hager's test, Wagner's test), carbohydrates (Molisch's test), reducing sugars (Fehling's test), saponins (Foam test), tannins ( $\mathrm{FeCl} 3$ test), flavonoids (Alkali test), phenolic compounds (Ferric chloride test) and proteins (Biuret test) [18].

2.6. PTZ-Induced Convulsions. Animals were divided into 12 different groups $(n=6)$. Vehicle, methanolic extract and different fractions of extract at specified doses were administered $30 \mathrm{~min}$ before induction of convulsions. Convulsions were induced by intraperitoneal injection of PTZ $\left(75 \mathrm{mg} \mathrm{kg}^{-1}\right)$. The animals were divided into different groups as follows:

Group 1. control group (vehicle treated).

Group 2. standard group (Diazepam $4 \mathrm{mg} \mathrm{kg}^{-1}$, i.p.).

Group 3. diazepam (1 $\mathrm{mg} \mathrm{kg}^{-1}$, i.p. $)$.

Group 4. crude extract (fraction 1) (1000 $\mathrm{mg} \mathrm{kg}^{-1}$, i.p.).

Group 5. crude extract (fraction 1) (1500 $\mathrm{mg} \mathrm{kg}^{-1}$, i.p.).

Group 6. crude extract (fraction 1) (2000 $\mathrm{mg} \mathrm{kg}^{-1}$, i.p.).

Group 7. chloroform fraction (fraction 2) $\left(20 \mathrm{mg} \mathrm{kg}^{-1}\right.$, i.p.);

Group 8. phenolic compound fraction (fraction 3) (1 $\mathrm{mg} \mathrm{kg}^{-1}$, i.p.).

Group 9. liriodendrin-rich fraction (fraction 4) (10 $\mathrm{mg} \mathrm{kg}^{-1}$, i.p.). 


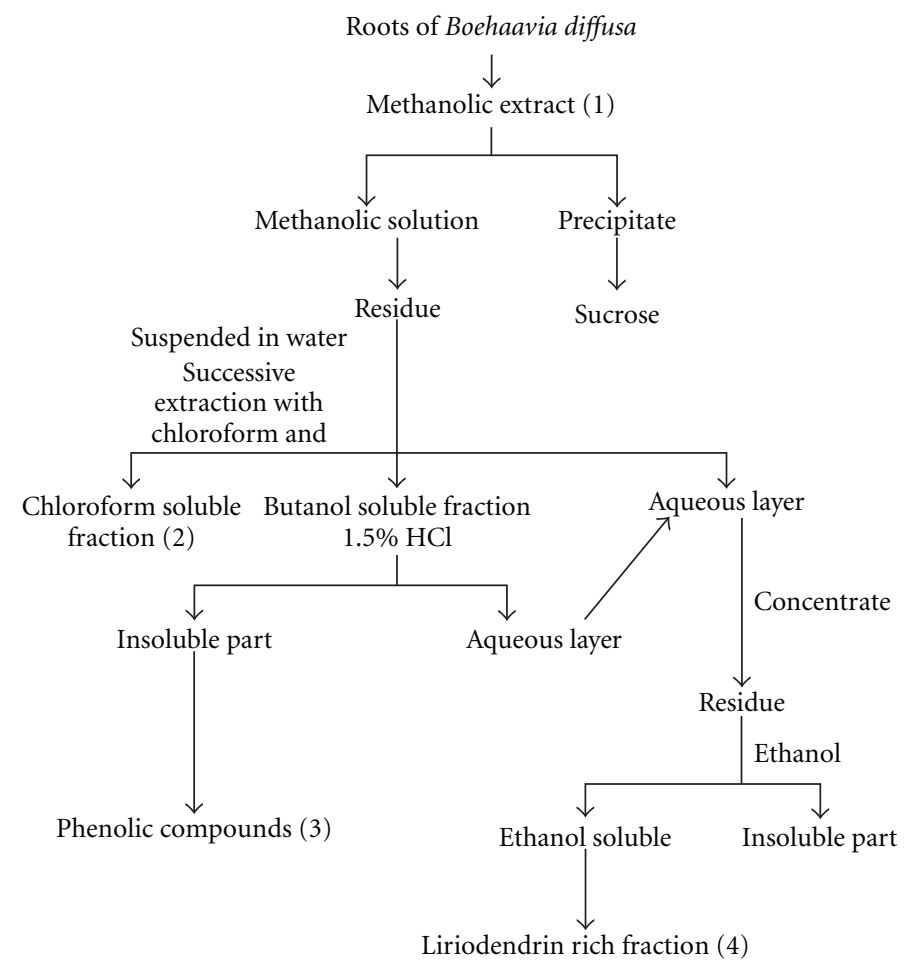

Figure 1: Scheme for extraction of roots of $B$. diffusa.

Group 10. liriodendrin-rich fraction (fraction 4) (20 $\mathrm{mg} \mathrm{kg}-1$, i.p.).

Group 11. liriodendrin-rich fraction (fraction 4) (40 $\mathrm{mg} \mathrm{kg}{ }^{-1}$, i.p.).

Group 12. liriodendrin-rich fraction (fraction 4) (20 mg kg-1, i.p.) +Diazepam ( $1 \mathrm{mg} \mathrm{kg}^{-1}$, i.p.).

In all groups the latency to clonic convulsions and mortality was noted [19]. The severity of convulsions was scored as follows: Each phase was given a numeric score: unresponsiveness $=0$, mild contractions $=1$, clonic seizures $=2$, tonic seizures $=3$ and death $=4$. The response of each animal was scored according to the highest phase reached and mean severity score was calculated for each group [20]. All the treated groups were compared with vehicle treated controls respectively in order to determine the significant anti-convulsant activity.

2.7. BAY k-8644-Induced Seizures. In order to elucidate the calcium channel antagonistic action of liriodendrin-rich fraction, animals were divided into four different groups $(n=6)$. Vehicle and liriodendrin-rich fraction $(10,20$ and $40 \mathrm{mg} \mathrm{kg}^{-1}$ ) were administered $30 \mathrm{~min}$ prior to the intracerebroventricular injection of BAY k-8644 $(37.5 \mu \mathrm{g})$. Seizures induced were rated according to the scale devised by: stage 1, scratching and twisting of the forelimbs (score 1); stage 2 , rearing and walking (score 2 ); stage 3 , intermittent clonic jerks of limbs with tonic flexion of fore limbs and tail flexion; stage 4 , head bobbing with complex grooming actions (licking of fur and scratching); stage 5, jumping, squeaking and tonic extension of hind limbs; stage 6, barrel rolling. The occurrence of clonic and tonic seizure signs and their latency were recorded for $50 \mathrm{~min}$. Mortality in the animals was observed for $8 \mathrm{~h}$ after BAY k-8644 injection [21]. The animals were divided into different groups as follows:

Group 13. control group (vehicle-treated).

Group 14. liriodendrin-rich fraction (fraction 4) (10 $\mathrm{mg} \mathrm{kg}^{-1}$, i.p.).

Group 15. liriodendrin-rich fraction (fraction 4) (20 $\mathrm{mg} \mathrm{kg}^{-1}$, i.p.).

Group 16. liriodendrin-rich fraction (fraction 4) (40 $\mathrm{mg} \mathrm{kg}^{-1}$, i.p.).

2.8. Statistical Analysis. Results were expressed as mean \pm standard error of mean (SEM). The significance of difference between mean was determined by one-way ANOVA test followed by Tukey's; test except the mortality data which was subjected to chi-square test and the results were regarded as significant at $P<.05$.

\section{Results}

3.1. Extraction and Preliminary Phytochemical Screening. The yield of the crude methanolic extract (fraction 1) was found to be $10.8 \% \mathrm{w} / \mathrm{w}$. The yield of fraction 2 of 
TABle 1: Phytoconstituents in B. diffusa methanolic extract and its various fractions.

\begin{tabular}{|c|c|c|c|c|}
\hline $\begin{array}{l}\text { Phytoconstituents } \\
\text { (test) }\end{array}$ & $\begin{array}{c}\text { Crude } \\
\text { methano- } \\
\text { lic extract } \\
{[1]}\end{array}$ & $\begin{array}{c}\text { Fraction } \\
2\end{array}$ & $\begin{array}{c}\text { Fraction } \\
3\end{array}$ & $\begin{array}{c}\text { Fraction } \\
4\end{array}$ \\
\hline \multicolumn{5}{|l|}{ Alkaloids } \\
\hline Hager's test & + & + & - & - \\
\hline \multicolumn{5}{|l|}{ Carbohydrates } \\
\hline Molisch's test & + & + & - & + \\
\hline \multicolumn{5}{|l|}{ Tannins } \\
\hline $\mathrm{FeCl}_{3}$ test & + & - & - & - \\
\hline \multicolumn{5}{|l|}{ Amino acids } \\
\hline Ninhydrin test & + & + & - & - \\
\hline \multicolumn{5}{|l|}{ Saponins } \\
\hline Foam test & + & + & - & - \\
\hline \multicolumn{5}{|l|}{ Flavonoids } \\
\hline Alkali test & + & + & - & - \\
\hline $\begin{array}{l}\text { Phenolic } \\
\text { compounds }\end{array}$ & + & - & + & - \\
\hline
\end{tabular}

+: present; -: absent.

the methanolic extract, that is, chloroform fraction was $1.32 \% \mathrm{w} / \mathrm{w}$, fraction 3 (phenolic compound fraction) was $0.07 \% \mathrm{w} / \mathrm{w}$ and liriodendrin-rich fraction was $1.4 \% \mathrm{w} / \mathrm{w}$. Preliminary phytochemical screening showed the presence of alkaloids, carbohydrates, reducing sugars, phenolic compounds, tannins, flavonoids, amino acids and saponins in the crude methanolic extract. In case of different fractions obtained from the crude methanolic extract: fraction 2 showed the presence of alkaloids, carbohydrates, amino acids and flavonoids, fraction 3 showed the presence of phenolic compounds and fraction 4 revealed the presence of carbohydrates and amino acids (Table 1).

3.2. PTZ-Induced Convulsions. Anti-convulsant studies with $B$. diffusa extract showed a significant protection against PTZ-induced convulsions in a dose-dependent manner. There was a significant $(P<.05)$ delay in the onset of convulsions and reduction in mortality at all the three doses of crude extract (fraction 1) (1000, 1500 and $2000 \mathrm{mg} \mathrm{kg}^{-1}$ ) in PTZ model, as compared with vehicle control group. The different fractions from the crude methanolic extract, that is, fraction $2\left(20 \mathrm{mg} \mathrm{kg}^{-1}\right)$, fraction $3\left(1 \mathrm{mg} \mathrm{kg}^{-1}\right)$ and fraction $4\left(10,20\right.$ and $\left.40 \mathrm{mg} \mathrm{kg}^{-1}\right)$ were also tested in PTZ model for their possible anti-convulsant activity. Fractions 2 and 3 showed no protection against PTZ-induced convulsions even at higher doses (data not shown) and complete mortality was observed in all of these groups. Among the different fractions only fraction 4 showed a significant $(P<.05)$ delay in the onset of convulsions and reduced mortality at all the three doses of extract $\left(10,20\right.$ and $\left.40 \mathrm{mg} \mathrm{kg}^{-1}\right)$ in PTZ model in a dose-dependent manner showing maximum protection at $40 \mathrm{mg} \mathrm{kg}^{-1}$ dose. The activity of liriodendrinrich extract when combined with sub-effective dose of diazepam $\left(1 \mathrm{mg} \mathrm{kg}^{-1}\right)$ showed synergistic effect as the effect

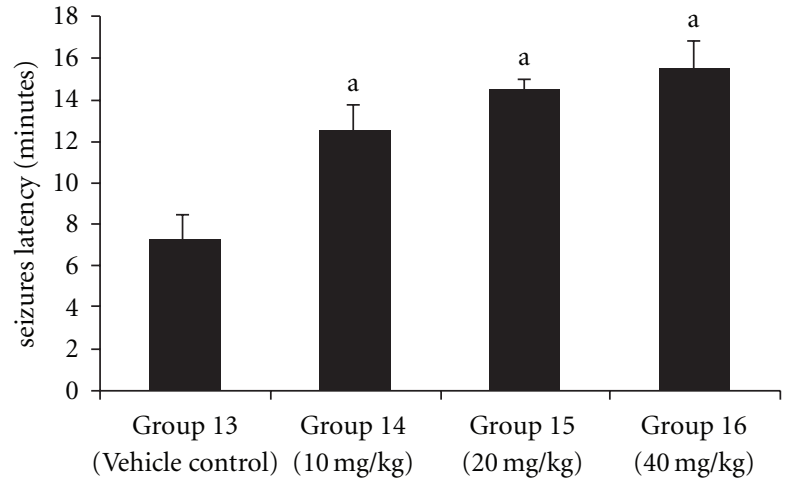

FIGURE 2: Effect of liriodendrin-rich fraction on the latency of seizures induced by BAY k-8644. ${ }^{\mathrm{a}} P<.05$ as compared with vehicle control group.

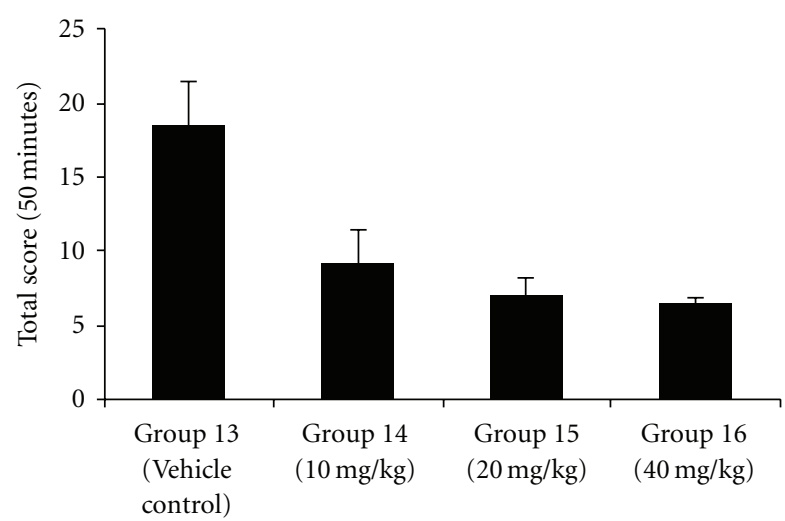

FIGURE 3: Effect of liriodendrin-rich fraction on the severity of seizures induced by BAY k-8644. ${ }^{\mathrm{a}} P<.05$ as compared with vehicle control group.

of combined treated group was significantly better than either diazepam $\left(4 \mathrm{mg} \mathrm{kg}^{-1}\right)$ or liriodendrin-rich fraction (40 $\mathrm{mg} \mathrm{kg}^{-1}$ ) per se treatment (Table 2).

3.3. BAY k-8644-Induced Seizures. Pretreatment with liriodendrin-rich fraction showed protection against BAY k-8644-induced seizures. Liriodendrin-rich fraction-treated groups showed a significant $(P<.05)$ delay in the onset (Figure 2 ) and reduction in the severity (Figure 3 ) of seizures induced by BAY k-8644 in a dose-dependent manner as compared with vehicle control group.

\section{Discussion}

In the present study PTZ was used to induce convulsions owing to the role of calcium ion as a common mediator in PTZ-induced convulsions [22]. This model was suitable for testing our hypothesis that the anti-convulsant activity of $B$. diffusa roots might be due to calcium channel blocking effect by liriodendrin. A significant protection was 
TABLE 2: Effect of different fractions of methanolic extract of B. diffusa on PTZ-induced convulsions in acute treatment studies.

\begin{tabular}{|c|c|c|c|c|}
\hline $\begin{array}{l}\text { Treatment/dose } \\
\left(\mathrm{mg} \mathrm{kg}^{-1}\right)\end{array}$ & $\begin{array}{c}\text { Onset of } \\
\text { convulsions }(\mathrm{min}) \\
(\text { mean } \pm \text { SEM })\end{array}$ & $\begin{array}{l}\text { Number of animals } \\
\text { showing } \\
\text { convulsions }\end{array}$ & $\begin{array}{l}\text { Severity score } \\
(\text { mean } \pm \text { SEM })\end{array}$ & Mortality (\%) \\
\hline $\begin{array}{l}\text { Vehicle control } \\
\left(75 \mathrm{mg} \mathrm{kg}^{-1}\right)\end{array}$ & $1.21 \pm 0.06$ & $6 / 6$ & $4.00 \pm 0.00$ & 100 \\
\hline Diazepam (4 mg kg $\left.{ }^{-1}\right)$ & $\mathrm{NC}$ & $0 / 6$ & 0 & 0 \\
\hline Diazepam (1 mg kg-1) & $2.13 \pm 0.07$ & $6 / 6$ & $3.66 \pm 0.23$ & 66.6 \\
\hline $\begin{array}{l}\text { Crude extract } \\
\left(1000 \mathrm{mg} \mathrm{kg}^{-1}\right)\end{array}$ & $3.97 \pm 0.11^{\mathrm{a}}$ & $4 / 6$ & $3.66 \pm 0.21$ & 66.6 \\
\hline $\begin{array}{l}\text { Crude extract } \\
\left(1500 \mathrm{mg} \mathrm{kg}^{-1}\right)\end{array}$ & $4.28 \pm 0.06^{\mathrm{a}}$ & $3 / 6$ & $3.33 \pm 0.33$ & 50 \\
\hline $\begin{array}{l}\text { Crude extract } \\
\left(2000 \mathrm{mg} \mathrm{kg}^{-1}\right)\end{array}$ & $11.33 \pm 0.46^{\mathrm{a}}$ & $1 / 6$ & $1.66 \pm 0.50^{a}$ & $16.6^{\mathrm{a}}$ \\
\hline $\begin{array}{l}\text { Chloroform fraction } \\
\left(20 \mathrm{mg} \mathrm{kg}^{-1}\right)\end{array}$ & $2.10 \pm 0.10$ & $5 / 6$ & $3.83 \pm 0.17$ & 83.3 \\
\hline $\begin{array}{l}\text { Phenolic compound } \\
\text { fraction }\left(1 \mathrm{mg} \mathrm{kg}^{-1}\right)\end{array}$ & $1.53 \pm 0.05$ & $6 / 6$ & $4.0 \pm 0.00$ & 100 \\
\hline $\begin{array}{l}\text { Liriodendrin-rich } \\
\text { fraction }\left(10 \mathrm{mg} \mathrm{kg}^{-1}\right)\end{array}$ & $2.49 \pm 0.19^{\mathrm{a}}$ & $4 / 6$ & $3.33 \pm 0.33$ & 66.6 \\
\hline $\begin{array}{l}\text { Liriodendrin-rich } \\
\text { fraction }\left(20 \mathrm{mg} \mathrm{kg}^{-1}\right)\end{array}$ & $4.20 \pm 0.52^{\mathrm{a}}$ & $2 / 6$ & $2.00 \pm 0.63^{\mathrm{a}}$ & $33.3^{\mathrm{a}}$ \\
\hline $\begin{array}{l}\text { Liriodendrin-rich } \\
\text { fraction }\left(40 \mathrm{mg} \mathrm{kg}^{-1}\right)\end{array}$ & $3.07 \pm 0.05^{\mathrm{a}}$ & $0 / 6$ & $1.83 \pm 0.48^{\mathrm{a}}$ & 0 \\
\hline $\begin{array}{l}\text { Liriodendrin-rich } \\
\text { fraction }\left(20 \mathrm{mg} \mathrm{kg}^{-1}\right)+ \\
\text { Diazepam }\left(1 \mathrm{mg} \mathrm{kg}^{-1}\right)\end{array}$ & $\mathrm{NC}$ & $0 / 6$ & 0 & 0 \\
\hline
\end{tabular}

${ }^{a} P<.05$ as compared with vehicle control group.

observed at all the three dose levels of crude methanolic extract of $B$. diffusa roots reiterating its earlier reports of anti-convulsant activity. Therefore the crude methanolic extract was further fractionated to obtain different fractions of methanolic extract rich in different phytoconstituents. Based on the presence of different phytoconstituents in different fractions of the methanolic extract we tried to investigate the component responsible for its anti-convulsant action. As reported, chloroform fraction of the methanolic extract contains fatty acids, sterol glycosides, syringaresinol mono- $\beta$-d-glucopyranoside and flavonoids [16]. Based on the presence of flavonoids in chloroform fraction it was hypothesized that the activity of methanolic extract might be because of this fraction. As it has been well reported in literature that flavonoids enhance gamma amino butyric acid (GABA) neurotransmission and GABA is the main inhibitory neurotransmitter which is suppressed in epilepsy [23]. Most of the anti-epileptic drugs act by enhancing GABA neurotransmission. It is well documented that in PTZ-induced convulsion model, PTZ exerts its convulsive effect by inhibiting the activity of $\mathrm{GABA}$ at $\mathrm{GABA}_{\mathrm{A}}$ receptors [24] that is why chloroform fraction was the first one among other fractions of methanolic extract to be tested for its anti-convulsant action. But this fraction failed to show any significant protection indicating that the anti-convulsant activity of $B$. diffusa is not because of flavonoids present in chloroform fraction.
The third fraction of the extract containing phenolic compounds was also evaluated in PTZ-induced convulsions with the notion that some phenolic compounds like maltol and other polyphenolic compounds have exhibited antiepileptic activity [25]. However, this fraction too failed to show protection indicating that the anti-convulsant activity of $B$. diffusa is not because of phenolic compounds present in the methanolic extract.

Finally with pretreatment of fraction 4, that is, liriodendrin-rich fraction, a maximum of $80 \%$ protection was observed, which was in accordance with the anticonvulsant activity of crude methanolic extract. Liriodendrin has been reported as a calcium channel blocker [16] and several studies indicate that dihydropyridine (calcium channel antagonists) has anti-convulsant properties [26, 27]; therefore the anti-convulsant action of liriodendrin-rich fraction may be due to its calcium channel antagonistic activity. In concordance with the earlier reports of calcium channel antagonist showing synergistic action with diazepam [28], in the present study diazepam synergized anti-convulsant activity of liriodendrin-rich fraction, thus indicating $B$. diffusa as a good adjuvant to conventional anti-epileptic drug therapy.

Attenuation of seizures induced by BAY k-8644 finally confirmed the role of calcium antagonism in the anticonvulsant activity of liriodendrin-rich fraction of $B$. diffusa, thus approving our hypothesis (Figure 4). 


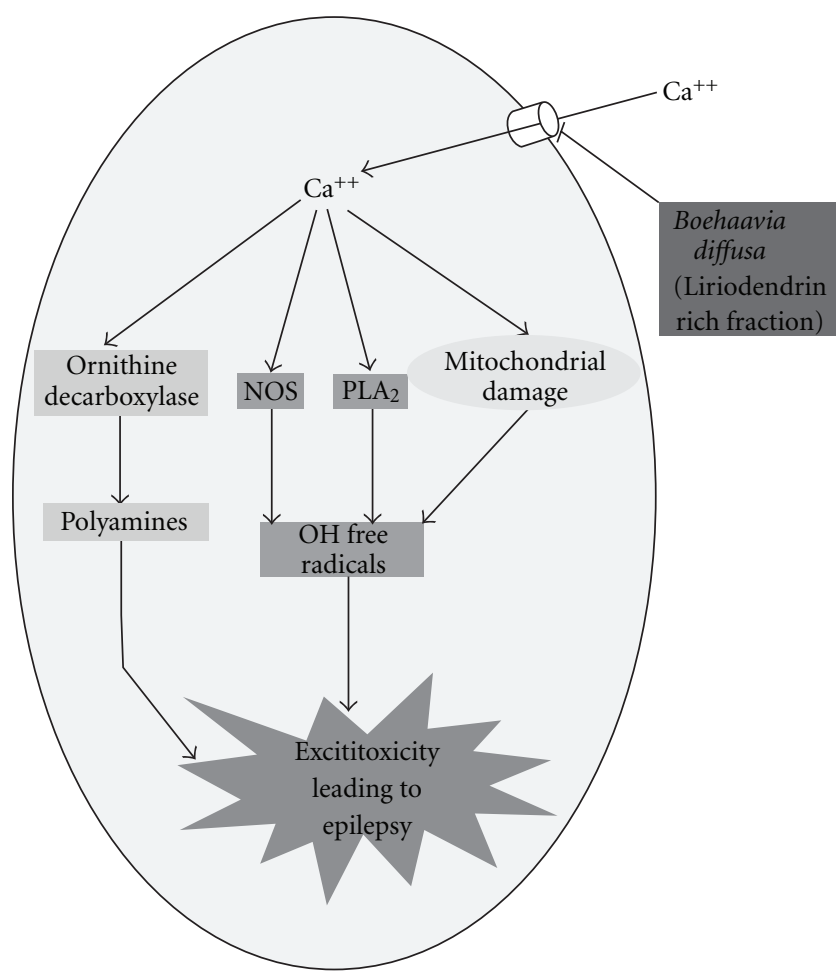

FIGURE 4: Schematic representation of anti-convulsant mechanism of B. diffusa.

\section{Conclusions}

The findings of the present study suggested that the methanolic extract of $B$. diffusa roots had anti-convulsant activity against PTZ-induced convulsions. As this activity retained only in liriodendrin-rich fraction, this confirms that the anti-convulsant activity of the crude methanolic extract is due to the presence of liriodendrin. Furthermore, protection of BAY k-8644-induced seizures by liriodendrin-rich fraction substantiates that the activity of liriodendrin is due to its calcium channel antagonistic properties.

\section{Funding}

Punjabi University, Patiala, India.

\section{References}

[1] E. L. Cooper, "Ayurveda is embraced by eCAM," EvidenceBased Complementary and Alternative Medicine, vol. 5, no. 1, pp. 1-2, 2008.

[2] M. L. Dhar, M. M. Dhar, B. N. Dhawan, B. N. Mehrotra, and C. Ray, "Screening of Indian plants for biological activity: part I," Indian Journal of Experimental Biology, vol. 6, pp. 232-247, 1968.

[3] K. R. Kirtikar and B. D. Basu, Indian Medicinal Plants, vol. III, Lalit Mohan Basu, Allahabad, India, 2nd edition, 1956.

[4] P. A. Akah and A. I. Nwambie, "Nigerian plants with anticonvulsant property," Fitoterapia, vol. 64, no. 1, pp. 42-44, 1993.
[5] B. B. Gaitonde, H. J. Kulkarni, and S. D. Nabar, "Diuretic activity of punarnava (Boerhaavia diffusa)," Bull Haffkine Institute, vol. 2, p. 24, 1974.

[6] G. K. Jain and N. M. Khanna, "Punarnavoside: a new antifibrinolytic agent from Boerhaavia diffusa Linn," Indian Journal of Chemistry, vol. 28, no. 2, pp. 163-166, 1989.

[7] D. K. Olukoya, N. Idika, and T. Odugbemi, "Antibacterial activity of some medicinal plants from Nigeria," Journal of Ethnopharmacology, vol. 39, no. 1, pp. 69-72, 1993.

[8] A. K. S. Rawat, S. Mehrotra, S. C. Tripathi, and U. Shome, "Hepatoprotective activity of punaranava-a popular Indian ethnomedicine," Journal of Ethnopharmacology, vol. 56, no. 1 , pp. 61-66, 1997.

[9] A. K. Nadkarni and P. K. Nadkarni, Indian Materia Medica, vol. I, Popular Prakashan Pvt. Ltd., Bombay, India, 1976.

[10] S. K. Adesina, "Anti-convulsant properties of the roots of Boerhaavia diffusa," Quarterly Journal of Crude Drug Research, vol. 17, pp. 84-86, 1979.

[11] M. K. Singh, S. Usha, S. C. Singh, and U. Singh, "Phytoecological investigations of Boerhavia diffusa Linn of Darbhanga district, Bihar," Neo-Botanical, vol. 2, pp. 61-64, 1994.

[12] A. N. Sahu, L. Damiki, G. Nilanjan, and S. Dubey, "Phytopharmacological review of Boerhaavia diffusa Linn.(Punarnava)," Pharmacognosy Reviews, vol. 2, pp. 14-22, 2008.

[13] T. N. Bhalla, M. B. Gupta, and K. P. Bhargava, "Antiinflammatory activity of Boerhaavia diffusa L," Indian Journal of Medical Research, vol. 6, pp. 11-15, 1971.

[14] M. A. Chude, O. E. Orisakwe, O. J. Afonne, K. S. Gamaniel, O. H. Vongtau, and E. Obi, "Hypoglycaemic effect of the aqueous extract of Boerhavia diffusa leaves," Indian Journal of Pharmacology, vol. 33, no. 3, pp. 215-216, 2001.

[15] R. Bharali, M. R. H. Azad, and J. Tabassum, "Chemopreventive action of Boerhaavia diffusa on DMBA-induced skin carcinogenesis in mice," Indian Journal of Physiology and Pharmacology, vol. 47, no. 4, pp. 459-464, 2003.

[16] N. Lami, S. Kadota, Y. Tezuka, and T. Kikuchi, "Constituents of the roots of Boerhaavia diffusa L. II. Structure and stereochemistry of a new rotenoid, boeravinone C2," Chemical and Pharmaceutical Bulletin, vol. 38, no. 6, pp. 1558-1562, 1990.

[17] N. Lami, S. Kadota, T. Kikuchi, and Y. Momose, "Constituents of the roots of Boerhaavia diffusa L. III. Identification of $\mathrm{Ca}^{2}$ channel antagonistic compound from the methanol extract," Chemical and Pharmaceutical Bulletin, vol. 39, no. 6, pp. 15511555, 1991.

[18] C. K. Kokate, A. P. Purohit, and S. B. Gokhale, Pharmacognosy, Nirali Prakashan, Pune, India, 28th edition, 2004.

[19] E. A. Swinyard, W. C. Brown, and L. S. Goodman, "Comparative assay of anti-epileptic drugs in mice and rats," Journal of Pharmacology and Experimental Therapeutics, vol. 106, pp. 319-330, 1952.

[20] J. Balter-Seri, Y. Yuhas, A. Weizman, Y. Nofech-Mozes, E. Kaminsky, and S. Ashkenazi, "Role of nitric oxide in the enhancement of pentylenetetrazole-induced seizures caused by Shigella dysenteriae," Infection and Immunity, vol. 67, no. 12, pp. 6364-6368, 1999.

[21] E.-J. Shin, T. Nabeshima, P. H. Lee et al., "Dimemorfan prevents seizures induced by the L-type calcium channel activator BAY k-8644 in mice," Behavioural Brain Research, vol. 151, no. 1-2, pp. 267-276, 2004.

[22] R. Shitak, A. K. Sahai, D. Hota, and A. Chakrabarti, "Evaluation of the modulatory role of nimodipine in seizures induced by kainic acid and pentylenetetrazol in mice," Methods and 
Findings in Experimental and Clinical Pharmacology, vol. 29, no. 1, pp. 11-17, 2007.

[23] J. B. Salgueiro, P. Ardenghi, M. Dias, M. B. C. Ferreira, I. Izquierdo, and J. H. Medina, "Anxiolytic natural and synthetic flavonoid ligands of the central benzodiazepine receptor have no effect on memory tasks in rats," Pharmacology Biochemistry and Behavior, vol. 58, no. 4, pp. 887-891, 1997.

[24] M. A. Rogawski, "Diverse mechanisms of antiepileptic drugs in the development pipeline," Epilepsy Research, vol. 69, no. 3, pp. 273-294, 2006.

[25] A. O. Ayoka, R. O. Akomolafe, E. O. Iwalewa, M. A. Akanmu, and O. E. Ukponmwan, "Sedative, antiepileptic and antipsychotic effects of Spondias mombin L. (Anacardiaceae) in mice and rats," Journal of Ethnopharmacology, vol. 103, no. 2, pp. 166-175, 2006.

[26] F. B. Meyer, R. E. Anderson, and T. M. Sundt Jr., "Suppression of pentylenetetrazole seizures by oral administration of a dihydropyridine Ca2+ antagonist," Epilepsia, vol. 28, no. 4, pp. 409-414, 1987.

[27] S. K. O’Neill and G. T. Bolger, "The effects of dihydropyridine calcium channel modulators on pentylenetetrazole convulsions," Brain Research Bulletin, vol. 25, no. 1, pp. 211-214, 1990.

[28] P. Khosla and P. Pandhi, "Anticonvulsant effect of nimodipine alone and in combination with diazepam on PTZ induced status epilepticus," Indian Journal of Pharmacology, vol. 33, no. 3, pp. 208-211, 2001. 


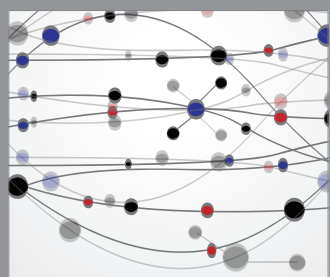

The Scientific World Journal
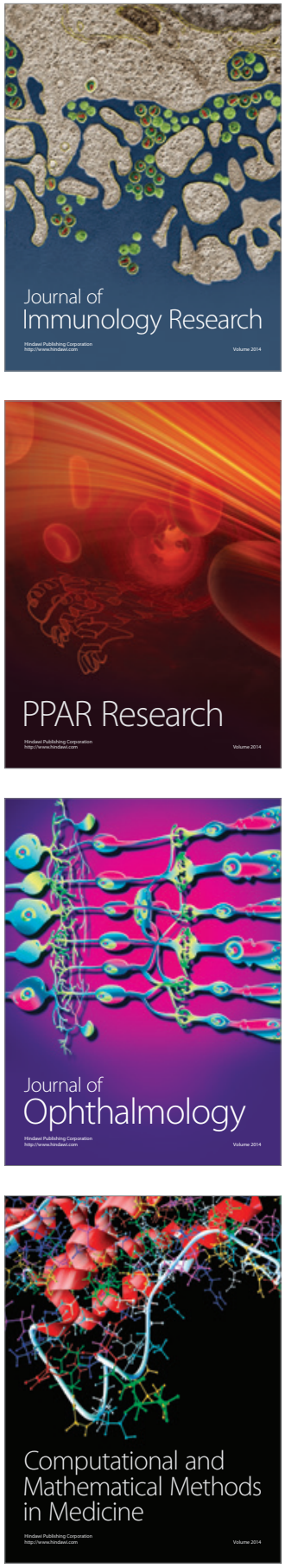

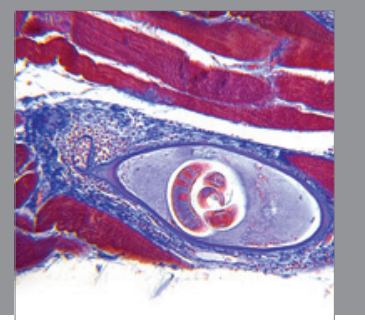

Gastroenterology

Research and Practice
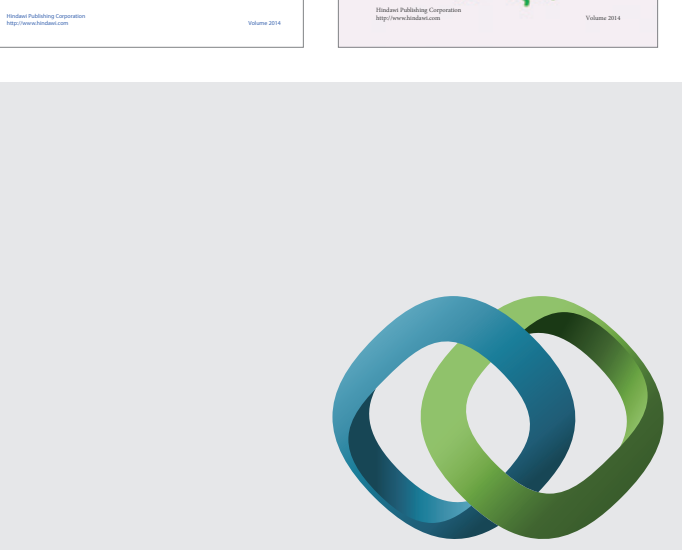

\section{Hindawi}

Submit your manuscripts at

http://www.hindawi.com
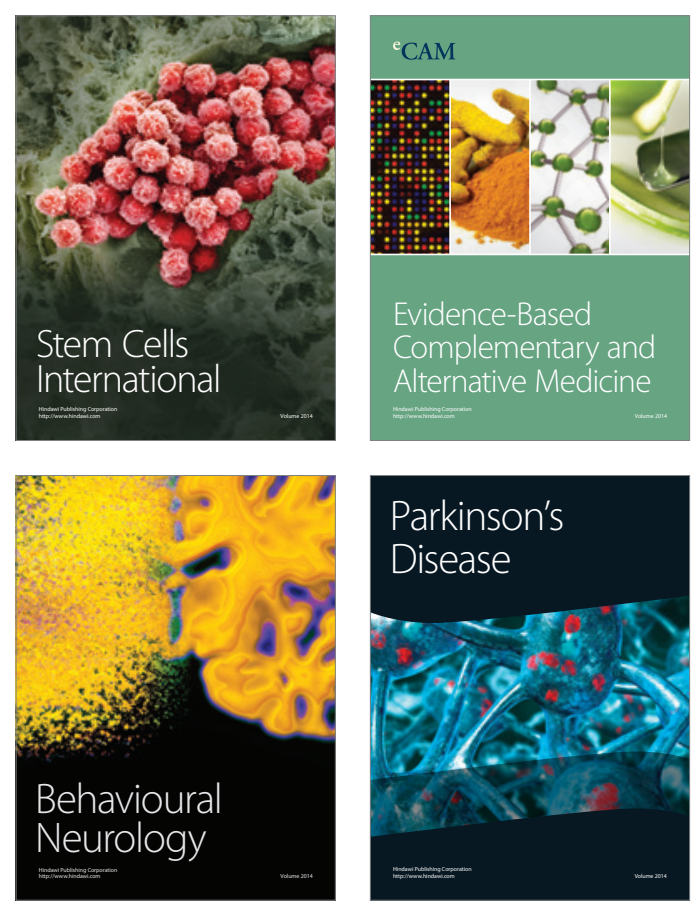

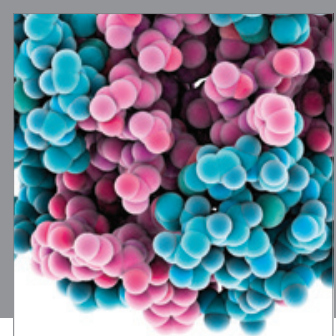

Journal of
Diabetes Research

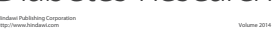

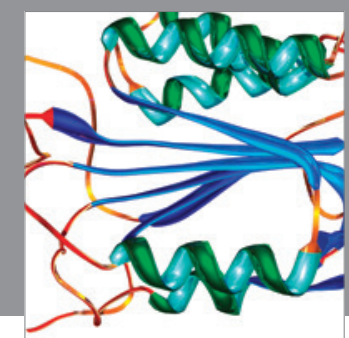

Disease Markers
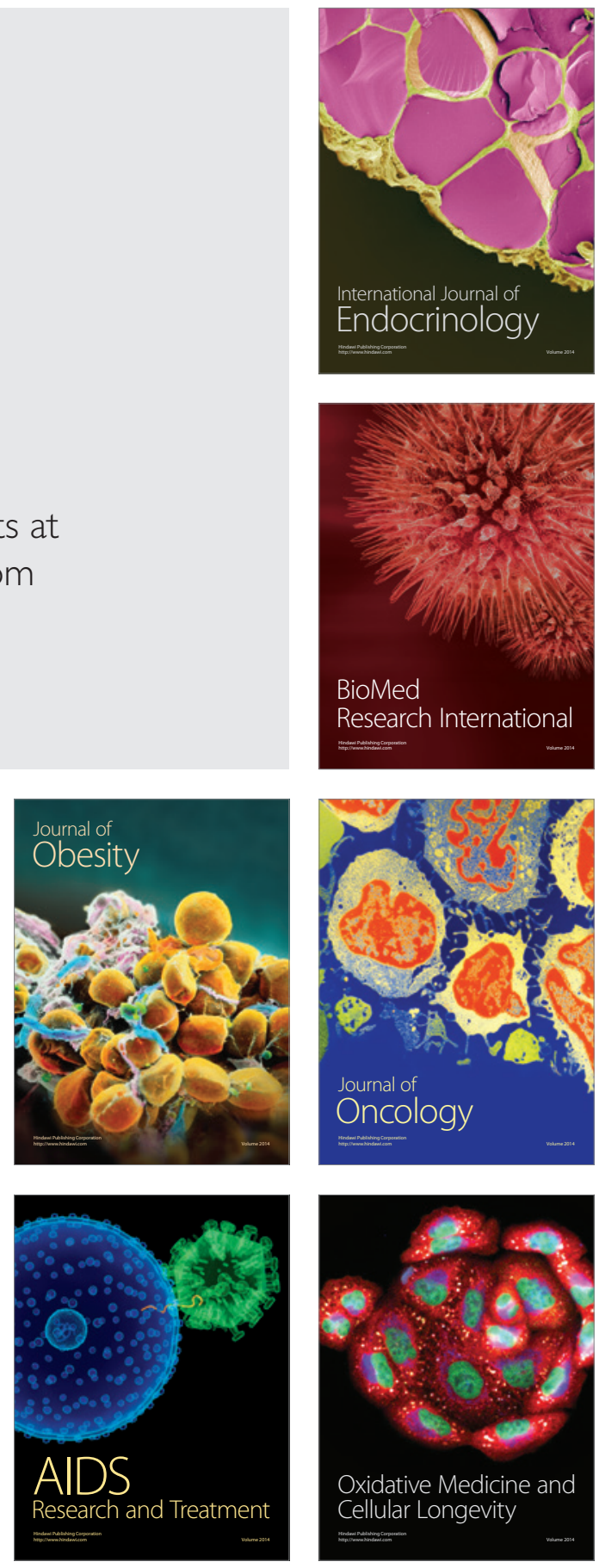